\title{
THE IMPORTATION OF COCCINELLID ENEMIES OF DIASPINE SCALES INTO PUERTO RICO
}

\author{
S. M. DOHANIAN, \\ Bureau of Entomology and Plant Quarantine, United States \\ Department of Agriculture.
}

One of the projects assigned to the writer in his recent investigations of beneficial insects in the American Tropics was the introduction of the predators of the coconut seale (Aspidiotus destructor Sign.) into Puerto Rico. This had been considered desirable in view of the presence of that pest in destructive numbers in Puerto Rico and the phenomenal success attained in its control in the Fiji Islands shortly after the introduction of coccinellids from Trinidad, B. W. I., in 1928. While this work was under way it was found possible to secure sufficient numbers of the different predators to provide shipments to Florida for use against the same pest and to California for testing upon the California red scale (Chrysomphalus aurantii Mask.).

The coconut palm is found throughout the Island of Puerto Rico, but extensive groves occur only along the seacoast, especially on the eastern and northeastern shores. Not only is Aspidiotus present wherever the coconut palm grows, but it attacks a dozen or more additional host plants. In Florida $A$. destructor is recorded from the southerly end of the peninsula and according to Merrill and Chaffin (1) it infests banana, mango, coconut, date, and Chinese fan.

\section{Coccinelulb Predators in Trinidad}

In Trinidad the coconut as an agricultural product is surpassed in importance only by cacao and sugarcane. In the southwestern corner and along practically the entire eastern shore of the island coconuts are grown almost to the exclusion of other crops. Numerous large plantations are seattered along the northern shore and in the northwestern corner of the island, as well as to the leeward of the northern range of mountains. Smaller groups of the palm may be found in other parts of the island. Nowhere are these trees free from the coconut scale. In the spring of 1936, however, although the infestation was general in distribution, the intensity was variable.

At least five species of coccinellid beetles have been recorded as predators on Aspidiotus destructor in Trinidad, Taylor (2) lists 
them as Cryptognatha nodiceps Marsh., C. simillima Sic., Azya trinitatis Marsh., Scymnus aencipennis Sic., and Pentilia insidiosa Muls. The present writer's investigations revealed three others, two being species of Hyperaspis and the third still undetermined. The species known in Trinidad as Pentilia insidiosa has been determined by coleopterists of the Bureau of Entomology and Plant Quarantine to be Pentilia castanea Muls., and by those of the California Citrus Experiment Station as Azya trinitatis Marsh. To avoid confusion the species will be referred to in this article as Pentilia castanea.

Two of the eight species represented in the writer's field collections overwhelmingly outnumbered all the others, nearly 90 percent of the insects shipped being Cryptognatha nodiceps and Pentilia castanea in about equal abundance. The former was common throughout the island and appeared in varying numbers in all the daily collections. In one region, however, it was exceeded in the numbers collected by $P$. castanea. In the groves along the eastern shore between Manzanilla and Biche and for 2 or 3 miles south of Biche, Pentilia was found in extraordinary abundance late in February and early in March, being fully three times as numerous as nodiceps. The other species encountered appeared to play an insignificant role in the control of Aspidiotus, and were never found in large numbers, at least not during the period of the writer's activities from January to March 1936. Yet, however small the representation of these minor species in the collections, they were always included in the shipments in the hope that under the conditions of their new envoronment they might become important factors in the control of this or some related pest. The two dominant species appeared to be much more searce in the inland coconut groves than in those along the shore, despite the absence of any appreciable difference in the intensity of Aspidiotus infestation. Was this due to soil conditions, to their isolation from the large groves, or to other undetermined factors? It would have been interesting to study the reasons for this condition, but time did not permit.

\section{Collection and Shipment}

In the field the beetles were collected in 4-inch glass vials. The daily collections were placed in cylindrical glass jars, 8 inches in diameter and 12 inches high. Some of these jars contained coconuts, one to each jar, and.others coconut fronds, heavily infested with Aspidiotus. This food was changed as necessary. Moisture was furnished daily by wetting the cheesecloth coverings of the jars. 
When sufficient numbers had accumulated to warrant an air-express shipment, the beetles were packed and shipped.

In Trinidad, as in many other tropical countries visited, Caucasian peoples sleep in beds sheltered by mosquito netting. Such protective covering is sometimes cylindrical and narrow at the top but wide enough at the bottom to cover the bed on all its sides, and sometimes rectangular, conforming to the size and shape of the bed. Such protection in vogue at the Imperial College of Tropical Agriculture, where the writer made his headquarters, was of the latter type, and in his work in Trinidad it served a double purpose. At night it eliminated annoyance by mosquitoes and numerous other similar pests, and the days that the beetles were to be prepared for shipment it provided a convenient cage for the separation of the species. The jars containing the adults were placed under this netting and the beetles allowed to escape a few at a time. As they alighted on the sides of the netting towards the source of light from the windows, they were gathered in 4-inch vials, five adults to a vial. When 10 to 15 vials contained their quota of beetles, they were taken to the window, examined, and classified, the numbers of each species being recorded, and were then placed in the shipping containers. The operation was repeated until all the beetles were examined.

The shipping containers were of the usual mailing-tube type used by Bureau workers in the United States. Additional roosting surface was provided in each by the insertion of a tightly fitting triangular piece of chicken wire $(1 / 4$-inch mesh) eut to size. Within its meshes were securely held two pieces of dental wick saturated, but not dripping, with a very dilute solution of sugar and water, to furnish water, humidity, and food. No host scales or any other food was furnished. The tubes were then wrapped in corrugated paper, and within its folds a slip of paper was placed bearing the numbers and species of the beetles therein, the dates and places of collection, the date of shipment, etc. In addition to the name and address of the consignee the following labels also were pasted on the outside of the package: "Permit of Entry of Beneficial Insects into the United States," "Rush," "Fragile," and "Handle with Care-Live Insects." Air express was used in all shipments.

\section{Species SHipped and Their Numbers}

Six consignments were forwarded from Trinidad, two of which went to Puerto Rico for liberation and breeding, two to Florida for direct liberation, and two to California for breeding in the laboratory 
and subsequent release in the spring. Both consignments to Puerto Rico were reported to have arrived in excellent condition. The first of the two lots sent to Florida also reached its destination in excellent condition and with only 2 percent mortality. The second shipment, however, was not released for several days after arrival owing to inclement weather, with a consequent heavy mortality of 73 percent. The first lot of beeties sent to California was a total loss, having frozen to death en route owing to misrouting somewhere in the United States. The second shipment had suffered a mortality of 52 percent upon reaching Riverside, Calif.

The numbers of the various species sent to the several destination, with the dates on which the shipments left Trinidad, are given in Table 1. Among the 11 individuals of unknown species included in the second consignment to California two species of Hyperaspis were represented, according to determinations by P. H. Timberlake.

TARLE1.-SPECIES AND NUMBERS OF COCCINELIID BEETLES SHIPPED FROM TRINIDAD TO PUERTO RICO AND THE UNITED STATES

\begin{tabular}{|c|c|c|c|c|c|c|c|c|c|c|}
\hline \multirow[b]{3}{*}{ Species } & \multicolumn{10}{|c|}{ Number of beetles shipped to- } \\
\hline & \multicolumn{3}{|c|}{ Puerto Rico } & \multicolumn{3}{|c|}{ Florida } & \multicolumn{3}{|c|}{ California } & \multirow[b]{2}{*}{ 氶 } \\
\hline & $\begin{array}{l}\underset{\text { 려 }}{\sim} \\
19\end{array}$ & 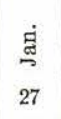 & 疍 & $\begin{array}{l}\stackrel{0}{0} \\
\text { í } \\
10\end{array}$ & $\begin{array}{l}\stackrel{\dot{\vec{F}}}{\mathrm{~F}} \\
10\end{array}$ & $\underset{\mathrm{E}}{\stackrel{\pi}{0}}$ & $\begin{array}{l}\frac{0}{0} \\
\text { |x } \\
10\end{array}$ & $\begin{array}{l}\stackrel{\dot{\Xi}}{\leftrightarrows} \\
10\end{array}$ & 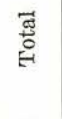 & \\
\hline 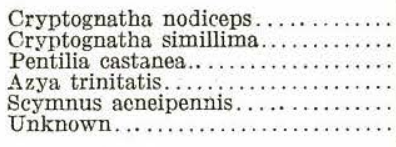 & $\begin{array}{r}147 \\
30 \\
38 \\
4 \\
3 \\
6\end{array}$ & $\begin{array}{r}126 \\
17 \\
30 \\
7 \\
14 \\
9 \\
\end{array}$ & $\begin{array}{r}273 \\
47 \\
68 \\
11 \\
17 \\
15 \\
\end{array}$ & $\begin{array}{r}156 \\
3 \\
25 \\
0 \\
6 \\
9\end{array}$ & $\begin{array}{r}149 \\
2 \\
595 \\
0 \\
16 \\
0\end{array}$ & $\begin{array}{r}305 \\
5 \\
620 \\
0 \\
22 \\
9 \\
\end{array}$ & $\begin{array}{r}174 \\
4 \\
46 \\
0 \\
0 \\
18 \\
\end{array}$ & $\begin{array}{r}111 \\
14 \\
141 \\
1 \\
66 \\
11 \\
\end{array}$ & $\begin{array}{r}285 \\
18 \\
187 \\
1 \\
66 \\
29 \\
\end{array}$ & $\begin{array}{r}863 \\
70 \\
875 \\
12 \\
105 \\
53 \\
\end{array}$ \\
\hline 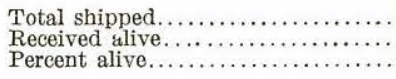 & $\begin{array}{r}228 \\
203 \\
89.0\end{array}$ & $\begin{array}{r}203 \\
197 \\
97.0\end{array}$ & $\begin{array}{r}431 \\
400 \\
92.8\end{array}$ & $\begin{array}{r}199 \\
194 \\
97.5\end{array}$ & $\begin{array}{r}762 \\
204 \\
26.8\end{array}$ & $\begin{array}{r}961 \\
398 \\
41.4\end{array}$ & $\begin{array}{r}242 \\
0 \\
0\end{array}$ & $\begin{array}{r}344 \\
163 \\
47.4\end{array}$ & $\begin{array}{r}586 \\
163 \\
27.8\end{array}$ & $\begin{array}{r}1,978 \\
961 \\
48.6\end{array}$ \\
\hline
\end{tabular}

\section{Present Status of the Imported Predators}

In a recent communication Harry S. Smith, of the Citrus Experiment Station, Riverside, Calif., stated:

"Cryptognatha nodiceps and Azya trinitatis reproduced on red scale (Chrysomphalus aurantii) infesting squash, but not in abundance. We sid not succeed in propagating the other species. On June 17, 1936, 110 Cryptognatha and two Azya were colonized at Santa Barbara on red scale. In May a breeding stock of both species was supplied to the Orange County Insectary. A considerable increase in the stock was obtained there, and several hundred adults were liberated in scale-infested groves. However, we have not 
yet observed propagation in the field. The species are still being propagated by the Orange County Insectary but it appears that our red seale is not a particularly favorable host for these beetles."

The Azya mentioned in Professor Smith's letter is the Pentitia castanea of the specialists of the Bureau of Entomology and Plant Quarantime.

To date we have no further information concerning developments in Florida.

No entomological explorer in foreign countries could wish for greater gratification than that experienced by the writer upon his return to Puerto Rico at the termination of investigations in Peru. On June 30, in company with K. A. Bartlett, of the Bureau of Entomology and Plant Quarantine, who received the shipments and made the original liberations of the predators, the writer collected the progeny of the two dominant species (Cryptognatha nodiceps and Pentilia castanea) which he had sent from Triniclad only five months earlier, for the purpose of further colonizations. Not only were these two species already well established in their new home, but they had multiplied so rapidly that it was possible to collect 332 adults in less than two hours. The feeling of satisfaction was heightened when, on July 16, the morning of his departure for Washington, the writer, again with Dr. Bartlett, found these two species 3 miles from the center of the original colony. The dispersion was in an easterly direction, towards the largest of the coconut groves on the island. Unfortunately, time was not available to continue the survey to determine the exact limits of dispersion.

Specimens collected in Puerto Rico and submitted to the experts of the Bureau for identification indicate the establishment of at least two other species of coccinellids sent from Trinidad in addition to those named.

One of the advantages of biological control work in tropical countries is that results become quickly lnnown. In temperate regions the establishment of beneficial insects may remain in doubt for several years, sometimes a decade or more. On the other hand, in the Tropics, where shorter life cycles and continuous breeding are the rule, the success or failure of attempts at biological control by introduced species may be determined in a comparativly short time.

\section{Literature Cited}

1. Merrill, G. B., and Chaffin, J. Scale Insects of Florida. Fla. State Plant Bd. Quart. Bull. 7 : 178-298, illus., 1923.

2. Taylor, T. H. C. The Campaign against Aspidiotus destructor, Sign., Fiji. Bull. Ent. Research 26, Part I : 1-100, illus., 1935. 